\title{
Evaluation of some heavy metal loading in the Kpeshi lagoon, Ghana
}

\author{
Joseph R. Fianko • Cynthia Laar • \\ Juilet Osei • Alfred K. Anim • \\ Abass Gibrilla • Dickson Adomako
}

Received: 7 September 2012/Accepted: 7 January 2013/Published online: 8 February 2013

(C) The Author(s) 2013. This article is published with open access at Springerlink.com

\begin{abstract}
A study was carried out on the Kpeshi lagoon to evaluate the relative contributions of some heavy metals ( $\mathrm{Na}, \mathrm{k}, \mathrm{Ca}, \mathrm{K}, \mathrm{Fe}, \mathrm{Mn}, \mathrm{Ni}, \mathrm{Cr}, \mathrm{Cd}, \mathrm{Al}, \mathrm{Pb}$ ) on the current state of the Kpeshi lagoon. The lagoon water was sampled along with some fish samples. Water $\mathrm{pH}$, electrical conductivity and total dissolved salts were measured in situ whilst $\mathrm{Na}$ and $\mathrm{K}$ were measured using flame emission spectrometry. Heavy metals (iron, manganese, nickel, aluminium, chromium, lead and cadmium) in both water and fish samples were analyzed using atomic absorption spectrometry. Measured $\mathrm{pH}$ values ranged between 6.60 and 7.87, a mean conductivity and total dissolved salts of $87.31 \pm 19.14 \mu \mathrm{S} / \mathrm{cm}$ and $38.4 \pm 8.43 \mathrm{mg} / \mathrm{L}$, respectively. Nutrient and organic matter were among the frequent source of pollution in the lagoon with mean sulphate, phosphate and nitrate concentrations of $190 \pm 108.84$, $1.62 \pm 0.49$ and $0.89 \pm 0.26 \mathrm{mg} / \mathrm{L}$, respectively. Iron and aluminium in the lagoon water measured the highest concentration of $13.2 \pm 3.47$ and $13.6 \pm 4.29 \mathrm{mg} / \mathrm{L}$, respectively. Fish samples however revealed very high concentrations of calcium and potassium measuring $15,709 \pm 75.35$ and $5,949.49 \pm 87.30 \mathrm{mg} / \mathrm{kg}$, respectively. Sodium and aluminium also revealed relatively high concentrations: $3,775.70 \pm 24.80$ and $708.47 \pm 4.95 \mathrm{mg} / \mathrm{kg}$, respectively. Notably, sites closer to settlement community
\end{abstract}

J. R. Fianko · C. Laar $(\bowtie) \cdot$ J. Osei · A. K. Anim ·

A. Gibrilla $\cdot$ D. Adomako

National Nuclear Research Institute, Ghana Atomic Energy

Commission, P. O. Box LG 80, Legon, Ghana

e-mail: adwoalaar@gmail.com

J. R. Fianko · C. Laar

School of Nuclear Sciences and Applications, Graduate School of Nuclear and Allied Sciences, University of Ghana,

P. O. Box AE1, Atomic Campus, Accra, Ghana
(Teshie Township, e.g. S1, S2, S3 and S4) and the hospitality industries (i.e. dotted hotels, e.g. S7) appeared to be relatively more contaminated.

Keywords Assessment · Bioaccumulation · Fish · Kpeshi lagoon · Metals $\cdot$ Pollution · Water

\section{Introduction}

Water is one of our most critical resources but, around the world and along with other natural resources, it is under threat. Comprising about $70 \%$ of the earth's surface, it is undoubtedly the most precious natural resource that exists on the planet. Although most nations recognize this fact, water bodies still remain the most polluted. Subsequently, living organisms both in water and those dependent on the very existence of this natural resource (including humans') are dying due to environmental pollution (Sherman and Sherman 1989). The Kpeshi lagoon located in the Greater Accra region of Ghana is one of the coastal lagoons which provide a source of livelihood for the fishing community within the Teshie Township. The lagoon and its aquatic resources have over the years suffered serious environmental degradation as a result of rapid urbanization with little regard to environmental planning.

The level of pollution in the Kpeshi lagoon is alarming. The once vibrant home to aquatic life has given way to the indiscriminate dumping of refuse, silt and toxic chemicals flowing into the sea and depleting the fish stock. A survey of the study area has shown for instance that human activities has created ecological pressure on the natural habitat of fish and other marine organism living in and around the lagoon. There is an upsurge of interest in water pollution as a result of this deleterious effect. Furthermore, 
factors such as high population growth accompanied by intensive urbanization, increase in industrial activities and higher exploitation of natural resources including cultivable land have all caused an increase in pollution in the lagoon. The wastes generated by squatter settlements, periurban agriculture and small scale industries are released into channels which eventually drain into the lagoon. This has resulted in deleterious effects not only on the lagoon but also to its fish resources. There has been a steady increase in discharges that reach the Kpeshi lagoon from both industries and settlements.

Heavy metals and other chemical contaminants are usually transported through the water, dissolved or associated to sediment particles (Laar et al. 2010). In addition to direct depletion of oxygen, the decomposition of large quantities of organic material in the water also produces inorganic nutrients such as ammonia, nitrate and phosphorus. These nutrients enrich the water considerably and give rise to dense algae growth or bloom. This can cause daily fluctuations in oxygen prescribed for fishes and in extreme condition, fish-kill can result. This increased productivity caused by excessive organic load can cause a decline in water quality (Smith et al. 1999).

The presence of metal pollutants in fresh water is known to disturb the delicate balance of the aquatic ecosystem. Fishes are often at the top of the aquatic chain and may concentrate large amounts of some metals from the water. Furthermore, fish is one of the most indicative factors in freshwater systems for the estimation of trace metals pollution and risk potential of human consumption (Sevket Kandemir et al. 2010). Fishes are notorious for their ability to concentrate heavy metals in their muscles and since they play important role in human nutrition, it is important to determine the concentrations of heavy metals in commercial fishes to evaluate the possible risk of fish consumption (Yilmaz et al. 2007). The accumulation of heavy metals in the tissues of organisms can result in chronic illnesses and cause potential damage to human population. In other to achieve sustainable development, environmental protection should constitute an integral part of the development process (Koukal et al. 2004). Developed countries have long identified major environmental hazards and some have successfully implemented monitoring and remediation programmes to minimize the risk involved while most developing countries including Ghana lack the implementation of such measures (Fianko et al. 2008). In the present study, it was aimed to evaluate the pollution level of Kpeshi lagoon via determining the accumulation of heavy metals in BlackChin tilapia samples. This paper deals with the effect of such development on the aquatic resources and discusses possible management considerations to mitigate further deterioration.

\section{Methodology}

Study area

Kpeshi lagoon is located $11 \mathrm{~km}$ west of Accra. The lagoon lies on latitude $5^{\circ} 34^{\prime} \mathrm{N}$ to $6^{\circ} 40^{\prime} \mathrm{N}$ and longitude $0^{\circ} 00^{\prime} \mathrm{E}$ to $0^{\circ} 8^{\prime} \mathrm{E}$. The lagoon is located on a low lying plain that is between Whitler Baracks corridor on the eastern side and the La-Trade fair. The effective catchment area of the wetland is approximately $22 \mathrm{~km}$ and comprises sand dunes, open lagoon, marshy lands and scrub lands.

The lagoon is connected to the sea through one broad opening (Kwei 1977). There are four different segments due to developments in the area. The first and second segments (S1 and S2) extend from the La-Trade Fair centre to the La-Palm Hotel with series of hospitality and recreation centres whilst the third section (S3) stretches from the Teshie Township; a local community. The fourth segment (S4) extends from the Zenith College-Exopa lane. The first and second segments have various inlets into the lagoon. The third and fourth are however gradually drying up. The major environmental stress has been the problem of siltation which to a large extent caused by run-off which erode unpaved areas in the catchments and transport the silt into the lagoon.

The chief source of pollution in the lagoon is the careless disposal of waste materials. Most of the waste materials come from the surrounding industries (mainly from the hospitality industry) and settlements located within the catchment in the form of refuse dumps and human excreta (Addo et al. 2011). Aquatic life of the lagoon has been greatly degraded due to contamination of its tributaries and the significant fishing industry supported by the lagoon is now seriously threatened.

\section{Sample collection}

Samples for chemical analysis were collected in precleaned, high-density 1-L polyethylene bottles that were rinsed three times with lagoon water before sample collection. Water samples were taken from mid stream at a depth of $20-30 \mathrm{~cm}$.

Electrical conductivity, $\mathrm{pH}$ and temperature were measured using well-calibrated digital sensors. Portable Hach Conductivity meter, Metrolin model 691-pH meter and mercury-in-glass thermometer were used to measure electrical conductivity, total dissolved solids (TDS) and $\mathrm{pH}$, respectively for sampling. Samples for chemical analysis were filtered in the laboratory through $0.45-\mu \mathrm{m}$ membrane filters using positive pressure. An aliquot from each sample was preserved with trace metal-grade nitric acid $(5 \mathrm{ml} 6 \mathrm{~N}$ $\mathrm{HNO}_{3}$ ) for cation analysis. All samples were transported on ice in ice-coolers to the laboratory and kept in a refrigerator below $4{ }^{\circ} \mathrm{C}$ prior to analysis. 
The fish samples were collected using fish nets from the Kpeshi lagoon and then fish samples. After capture, the fish samples were cleaned with deionized-distilled water, stored in pre-cleaned polyethylene bags, kept frozen in an ice box and transported to the laboratory for weighing and preparation. Selected samples were dissected and weight of tissue samples recorded and kept frozen at $-20{ }^{\circ} \mathrm{C}$ until experimental assays.

\section{Sample preparation and analysis}

Water samples were analyzed according to the standard methods for analysis of water and waste water (APHA 1992). Water samples collected in the field were analyzed for chemical constituents such as $\mathrm{BOD}, \mathrm{SO}_{4}{ }^{2-}, \mathrm{NO}_{3}{ }^{-}-\mathrm{N}$, $\mathrm{PO}_{4}{ }^{3-}-\mathrm{P}, \mathrm{Cl}^{-}$, total hardness and alkalinity, in the laboratory using the standard methods as prescribed by the American Public Health Association (APHA 1992). All reagents used were of analytical grade, equipments pre-calibrated appropriately prior to measurement and replicate analyses carried out for each determination. Analytical Instruments were precalibrated appropriately prior to measurement. Replicate analyses were carried out for each determination to ascertain reproducibility and quality assurance. Alkalinity was determined by titrimetry method. A $50 \mathrm{~mL}$ of the sampled water was pipette into a conical flask and two drops of methyl orange indicator added. The resulting yellow solution was then titrated against $0.2 \mathrm{M} \mathrm{HCl}$ to a pale pink endpoint.

Water samples for dissolved oxygen (DO) and biological oxygen demand (BOD) determination were collected separately into 300-ml BOD glass bottles. The samples were fixed on spot by adding $2 \mathrm{~mL}$ each of $\mathrm{MnSO}_{4}$ and alkali-oxide iodide solution and BOD determined by the Winkler Azide modification method. Samples for BOD were also collected into separate $300-\mathrm{mL}$ plastic bottles for incubation in a dark place for 5 days and measured using the Winkler azide modification method.

BOD was determined using the Winkler azide modification method. For the determination of dissolved oxygen, 300-mL BOD bottle was carefully filled with water sample to avoid trapping bubbles.

$\mathrm{Mn}_{(\mathrm{aq})}^{2+} \rightarrow \mathrm{Mn}(\mathrm{OH})_{2} \mathrm{O}$

then:

$4 \mathrm{Mn}(\mathrm{OH})_{2}+\mathrm{O}_{2} \rightarrow 4 \mathrm{MnO}(\mathrm{OH})+2 \mathrm{H}_{2} \mathrm{O}$

The $\mathrm{I}_{3}{ }^{-}$produced was determined by titration with thiosulphate:

$2 \mathrm{~S}_{2} \mathrm{O}_{3}^{2-}+3 \mathrm{I}^{-}$

From Eqs. 1, 2, and 3, the mole ratio of $\mathrm{O}_{2}$ to $\mathrm{S}_{2} \mathrm{O}_{3}{ }^{2-}$ (1:4) can be determined and hence the $\mathrm{mg} / \mathrm{L}$ of oxygen dissolved in the water samples calculate.
Flame emission photometric method was used to measure sodium and potassium. Trace amounts of potassium in the water samples were determined in a direct-reading type of flame photometer at a wavelength of $766.5 \mathrm{~nm}$ whilst trace amounts of sodium were determined at a wavelength of $589 \mathrm{~nm}$.

The amount of sulphate ions was determined by turbidimetric method using barium chloride (Hesse 1971). i.e. $\mathrm{mg} \mathrm{SO}_{4}^{2-}{ }_{\mathrm{g}} / \mathrm{L}=\mathrm{mg} \mathrm{SO}_{4}^{2-}{ }_{\mathrm{g}} \times 1,000 / \mathrm{mL}$ sample:

The analysis of phosphorus was determined by the ascorbic acid method using the Ultraviolet spectrometry (UV-1201) (AOAC 1995).

For the determination of total dissolved metals, water samples were digested in dilute hot acid solution to extract lightly absorbed particulate material present in the samples. Homogenized fish samples were also digested with concentrated nitric and perchloric acid (2:1) and the contents brought to a constant volume. Water and fish samples for heavy metal determination were analyzed using the VARIAN AA240FS Flame Atomic Absorption Spectrometer which is a fast multi-element technique with a dynamic linear range and moderate-low detection limits. To ensure the reliability of the analytical method during digestion and sample preparation, blanks and replicate analyses were carried out for each determination. All reagents used were of analytical grade, equipments precalibrated appropriately prior to measurement.

Cold vapour AAS was used in the determination of total dissolved mercury. The organomercury compounds in the sample were oxidized to inorganic mercury (II) compounds by heating with sulphuric acid, potassium permanganate and potassium persulphate. The mercury compounds were then reduced with stannous chloride in a hydroxylamine sulphate sodium chloride solution to elemental mercury. The mercury was spurge from solution with a stream of air and passed through an absorption cell situated in the pathway of the mercury lamp.

Laboratory fish homogenization and analysis

On receipt, 30 samples were randomly selected, washed with distilled water, weighed, and double bagged in separate polyethylene bags, sealed and labelled accordingly and kept frozen. The frozen fish samples were partially thawed on cleaned plastic sheets using scalpels with steel blades and plastic forceps. Whole taxa of a designated length range were cut into small pieces with stainless knife.

The fishes were placed in pre-weighed glass vials and freeze dried at about $70{ }^{\circ} \mathrm{C}$ to constant weight to free all the water in the fish samples.

Each fish sample (whole fish) was then blended and then put back into their respective vials and then digested using the nitric acid digestion method (APHA 1992) by adding 
$5 \mathrm{ml}$ of concentrated $\mathrm{HNO}_{3}$ and $1 \mathrm{~mL}$ of $\mathrm{H}_{2} \mathrm{O}_{2}$ analytical grade quality and heated on a microwave for several hours at about $70{ }^{\circ} \mathrm{C}$. The digested samples were then made up to $20 \mathrm{ml}$ mark each with de-ionized water. The contents were then filtered and kept in acid-washed polythene bottles until ready for the analyses to avoid the loss of metal ions due to adsorption. The samples were analyzed for elemental concentration using the AA 240 FS Atomic Absorption Spectrometer (AAS). Metal concentration in fish samples was calculated using the equation below (APHA 1992):

Metal concentration ( $\mathrm{mg} / \mathrm{kg}$ dry wt.)

$$
=\frac{\text { Conc. } \times \text { vol. of digested solution }}{\text { Dry weight of fish samples taken }}
$$

\section{Results and discussion}

Temperature is a key variable which affects the metabolic activity of aquatic organisms. Most tropical fishes grow best between 21 and $32{ }^{\circ} \mathrm{C}$, but are not able to survive below $15{ }^{\circ} \mathrm{C}$ for extended period of time (Swift 1993). The temperature recorded for the entire study ranged from 27.4 to $31.8{ }^{\circ} \mathrm{C}$. According to Biney (1990), this is typical of shallow coastal waters in Ghana, where ambient temperatures remain within a narrow range of $25-35^{\circ} \mathrm{C}$. An average temperature of $29.3{ }^{\circ} \mathrm{C}$ was recorded during the study period which is comparable to that obtained by Biney (1986) in the Kpeshi lagoon $29.4{ }^{\circ} \mathrm{C}$. The conductivity values measured during the study were generally very high for all the sampling sites and far exceeded the WHO and EPA permissible guideline values of 1,500 and $300 \mu \mathrm{S} / \mathrm{cm}$ for natural background level (Biney et al. 1995). The present study recorded a mean range in conductivity of $25.00-68.91 \mathrm{mS} / \mathrm{cm}$ with a mean value of $55.71 \mathrm{mS} / \mathrm{cm}$. Conductivity is the measure of the mineral content of a water body and represents the total quantity of dissolved materials in a sample of water. The high conductivity values may be attributed to the presence of dissolved solids in the waters. However, the high conductivity values measured at Sites 2, 4 and 6 could be attributed to high ionic exchange as a result of the human activities in the area such as the fishing and salt mining, as well as sand and stone winning in the catchment.

TDS ranged from 24.1 to $50.0 \mathrm{mg} / \mathrm{L}$ with a mean of $38.4 \mathrm{mg} / \mathrm{L}$. The highest TDS value of $50.0 \mathrm{mg} / \mathrm{L}$ was recorded at Site S6. The high TDS values in the lagoon waters could be attributed to the discharge of domestic waste that results in large quantities of silt and debris being carried into the lagoon. Tidal mixing wave action also increases TDS by causing fine sediment to re-suspend, and the resulting turbidity reduces light available for photosynthesis (Cloern 1996) thereby increasing the TDS levels.
High TDS in the lagoon could also be attributed to the degree of weathering and the chemical composition of rocks and by the relative influence of evaporation (Davies and Day 1998) as well as more turbid, particle-laden waters that enter lagoons at high tides.

The high level of TDS and conductivity in the coastal waters as presented in Table 1 may have a deleterious impact on the water and may make the water unsuitable for fish and other forms of aquatic life inhabiting it (Cunningham and Saigo 1997). High levels of dissolved solids will not be suitable for fish spawning since this will make it harder for fishes to find food and they can also destroy fish gill structures (Peirce et al. 1997). Damage due to abrasion of the gill epithelial tissue may vary from erosion of microvilli to necrosis of epithelium and destruction of lamellae. This results in reduced permeability to oxygen and may lead to homeostatic failure (WRC 2003).

Turbidity is a measure of the degree to which water loses its transparency due to the presence of suspended particulates. Measured turbidity values ranged from 14 to 91 FAU. There are various parameters that may influence the cloudiness of the water. Some of these are sediments from erosion, resuspended sediments from the bottom (frequently stir up by bottom feeders like carp), waste discharge, algae growth and urban runoff. The more total suspended solids in the water, the murkier it seems and the higher the turbidity (APHA 1992). The suspended particles also help the attachment of heavy metals and many other toxic organic compounds.

Because one of the primary factors affecting turbidity is total suspended solids, the factors affecting TSS will also affect turbidity. In addition, organic matter contributes to turbidity.

Total suspended solids (TSS) are solids in water that can be trapped by a filter. TSS measured in the waters ranged from 13 to 97 NTU. TSS can include a wide variety of material, such as silt, decaying plant and animal matter,

Table 1 Summary of the physico-chemical parameters at the Kpeshi lagoon

\begin{tabular}{lllc}
\hline Parameter & Minimum & Maximum & Mean $\pm \mathrm{SD}$ \\
\hline $\mathrm{pH}$ & 6.62 & 7.87 & $6.7 \pm 2.2$ \\
Temperature, ${ }^{\circ} \mathrm{C}$ & 30.2 & 33 & $31.6 \pm 3.94$ \\
Conductivity, mS/cm & 54.8 & 114.6 & $87.31 \pm 19.14$ \\
TDS, g/L & 24.1 & 50 & $38.43 \pm 8.43$ \\
Turbidity, FAU & 14 & 91 & $30.29 \pm 2.59$ \\
Total suspended solids & 13 & 97 & $28.86 \pm 3.08$ \\
BOD, ppm & 6.58 & 27.91 & $14.83 \pm 0.09$ \\
Alkalinity, ppm & 400 & 2,000 & $1057.14 \pm 499.52$ \\
$\mathrm{SO}_{4}{ }^{2-}, \mathrm{ppm}$ & 7,820 & 16,598 & $11852.0 \pm 2915.08$ \\
$\mathrm{PO}_{4}{ }^{3-}, \mathrm{ppm}$ & 240 & 880 & $487.14 \pm 257.02$ \\
\hline
\end{tabular}


industrial wastes and sewage. High concentrations of suspended solids can cause many problems for stream health and aquatic life.

Alkalinity values measured during the period were high, ranging from 122.7 to $188.6 \mathrm{mg} / \mathrm{L}$ for the sampling sites with an overall mean value of $137.4 \mathrm{mg} / \mathrm{L}$. High alkalinity values in the lagoon indicated that the water had a higher capacity to neutralize a change in $\mathrm{pH}$ (Chapman 1992). The waters at Site 7 were the most alkaline and this could be attributed to the continuous removal of vegetation. Landuse impacts (farming practices) which expose the soil and underlying rocks through the process of weathering could also result in the high alkalinity in the water.

Sodium concentrations ranged from 11,700 to 19,640 $\mathrm{mg} / \mathrm{L}$ with a mean concentration of $15,165.71 \mathrm{mg} / \mathrm{L}$. The highest value was measured at site S4. Concentrations of sodium in natural surface waters may vary considering local geological conditions and wastewater discharges. Values can range from $1 \mathrm{mg} / \mathrm{L}$ or less to $105 \mathrm{mg} / \mathrm{L}$ or more in natural brines (Chapman 1992). The WHO guideline limit for sodium in surface water is $200 \mathrm{mg} / \mathrm{L}$ and for ground-water levels frequently exceed $50 \mathrm{mg} / \mathrm{L}$ (Chapman 1992). Gordon (1995) measured a mean sodium concentration of $52,725 \mathrm{mg} / \mathrm{L}$ at the Kpeshi lagoon in the dry season. The very high sodium concentrations measured may be due to seawater intrusion.

Concentrations of potassium ranged between 500 and $980 \mathrm{mg} / \mathrm{L}$ with the highest concentration recording at site S3. The high potassium level recorded at Site 3 was an indication of the influence from domestic discharge and agricultural effluents especially fertilizers containing potassium through soil run off into the lagoon. Gordon (1995) recorded mean range of $211-1,900 \mathrm{mg} / \mathrm{L}$ for a similar study conducted at the lagoon which compares favourably with the results for the present study. The high mean level of potassium recorded at Site 3 indicated the discharge of domestic waste and agricultural effluents especially fertilizers containing high levels of potassium through soil run off into the lagoon.

According to Chapman (1992), atmospheric deposition and weathering of some rocks, industrial, agricultural and sewage effluents are known to contribute to the chloride concentration in surface waters. Chapman further argued that higher concentration of chloride in surface waters occurs near waste outlets and salt water intrusion. Sea intrusion could best be used to explain the relatively high values recorded for chloride levels during the study. The lower mean value of chloride recorded at site S7 could be due to the distance of the site from the intrusion of the sea water.

Concentrations of magnesium ranged from 184 to $364 \mathrm{mg} / \mathrm{L}$ with a mean concentration of $258 \mathrm{mg} / \mathrm{L}$ (Table 2). The relatively high levels of magnesium in the
Table 2 Metals in surface water from the Kpeshi lagoon

\begin{tabular}{lllc}
\hline Parameter, ppm & Minimum & Maximum & Mean $\pm \mathrm{SD}$ \\
\hline $\mathrm{Na}^{+}$ & 11,700 & 19,640 & $15165.71 \pm 2934.34$ \\
$\mathrm{~K}^{+}$ & 500 & 980 & $672.86 \pm 180.25$ \\
$\mathrm{Ca}^{2+}$ & 240 & 520 & $331.43 \pm 91.55$ \\
$\mathrm{Mg}^{2+}$ & 184 & 364 & $258 \pm 64.23$ \\
$\mathrm{Fe}$ & 3.0 & 13.2 & $8.29 \pm 3.47$ \\
$\mathrm{Mn}$ & 0.41 & 1.28 & $0.69 \pm 0.28$ \\
$\mathrm{Ni}$ & 2.8 & 9.2 & $4.71 \pm 2.25$ \\
$\mathrm{Cr}$ & 0.2 & 4.0 & $1.86 \pm 1.27$ \\
$\mathrm{Cd}$ & 0.4 & 1.4 & $0.7 \pm 0.29$ \\
$\mathrm{Al}$ & 1.8 & 13.6 & $7.51 \pm 3.29$ \\
$\mathrm{~Pb}$ & 1.8 & 11.6 & $4.96 \pm 3.89$ \\
\hline
\end{tabular}

lagoon can be attributed to the use of fertilizers by vegetable crop farmers which may contain high levels of the element. The pattern of ionic dominance in the lagoon during the present study was $\mathrm{Na}>\mathrm{Mg}>\mathrm{SO}_{4}>\mathrm{K}>$ $\mathrm{Ca}>\mathrm{HCO}_{3}{ }^{-}$and this was similar to $\mathrm{Na}>\mathrm{Mg}>\mathrm{Ca}>\mathrm{K}$ : $\mathrm{SO}_{4}>\mathrm{HCO}_{3}$ obtained by Biney (1986) for a study conducted in most coastal waters in Ghana.

Naturally, dissolved oxygen concentrations vary over a 24-h period due to tidal exchange. The relatively high dissolved oxygen levels at sampling sites 1, 2 and 3 could be attributed to the influence of wave action enriching sea water with oxygen unto these sites, whilst the low dissolved oxygen levels recorded at the other sampling sites were due to pollution from agricultural and domestic sewage (Biney 1984). Dissolved oxygen values greater than $5 \mathrm{mg} / \mathrm{L}$ are considered favourable for growth and activity of most aquatic organisms, whilst those less than $3 \mathrm{mg} / \mathrm{L}$ are considered stressful to most aquatic organisms. Dissolved oxygen concentration less than $2 \mathrm{mg} / \mathrm{L}$ may lead to the death of most fishes or does not support aquatic life (Chapman 1992). The amount of dissolved oxygen recorded in the lagoon is a good indicator of water quality and can support life since oxygen is involved in nearly all biological and chemical processes within water bodies. The observed level of dissolved oxygen in the lagoon is suitable for fish and other aquatic organisms (WRC 2003) and will increase appetite, growth and production of the fishes and other aquatic organisms in the lagoon. There would also be a decrease in susceptibility of the aquatic organisms inhabiting the lagoon to diseases (WRC 2003) because the lagoon is well oxygenated and most organisms would survive with the right amount of light intensity.

Relatively high concentrations of nutrients $\left(\mathrm{PO}_{4}{ }^{3-}\right.$ and $\mathrm{SO}_{4}{ }^{2-}$ ) were obtained. Within the hydrogeological and physical characteristics of the study area, the results indicate that nitrogen from sewage system and farmlands is the main cause of high nitrogen in the water. All water samples

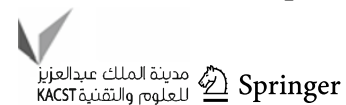


had nitrate levels above $10 \mathrm{mg} / \mathrm{L}$. Heavy precipitation and denitrification rate is believed to have influenced the nitrate content in the leached water.

Phosphorus is rarely found in high concentrations in surface waters as it is taken up by plants. In most natural surface waters phosphorus ranges from 0.005 to $0.060 \mathrm{mg} / \mathrm{L}$ (Wild 1995). Phosphate concentrations varied from 0.04 to $3.26 \mathrm{mg} / \mathrm{L}$. The relatively high phosphate concentrations in the lagoon may have the potential of causing eutrophication thereby reducing the level of oxygen in the lagoon needed by aquatic organisms especially fish for respiration. On the other hand, the very low levels of phosphate at sites S1, S4, S6 and S7 may also be as a result of some buffering mechanism, whereas phosphorus is released from or absorbed by the sediments depending on its concentration in the overlaying waters (Biney 1982).

The high levels of trace metals recorded in the lagoon water from the discharge of domestic waste and residues from agrochemicals used in the catchment by farmers may be carried to the water as runoff or through neglect or by eroding soil or percolating or leaching through the soil. Trace and heavy metals in the agrochemicals will cause widespread damage to biota. Animals may be poisoned by pesticide and fertilizer residues that remain on crops and food after spraying. Widespread application of the agrochemicals may eliminate food sources that certain types of animals need, causing the animals to relocate, change their diet or starve to death. High levels of trace metals recorded in the lagoon will bioaccumulate to enhance toxic levels in the bodies of organisms that consume them over time and they eventually die (Palmateer 1992).

Iron concentration for all the sampling sites were above the WRC target water quality range of $0.01 \mathrm{mg} / \mathrm{L}$. The higher concentrations in the lagoon may arise from landuse practices in the catchment. The higher levels recorded at Site S3 (Fig. 1) may be due to agricultural activities (the use of agrochemicals and fertilizers by farmers). Iron at very high levels is toxic and may inhibit enzymatic functions (WRC 2003) in aquatic organisms. Elevated levels of iron in coastal waters will also increase the susceptibility of the fishes in the lagoon to infectious diseases. Human activities are also a possible source for much of the manganese contamination in water in most areas.

Manganese can be released to water bodies by discharge from industrial facilities or as leachate from landfills and soil (Francis and White 1987). Disposal of mine tailings and liquor in the sea is another source of manganese to the coastal environment, particularly in tropical areas (Florence et al. 1994). Manganese occurs naturally in most surface waters and in soils that may erode into waters. However, human activities are also responsible for much of the manganese contamination in water in most areas. Manganese can be released to water bodies by discharge

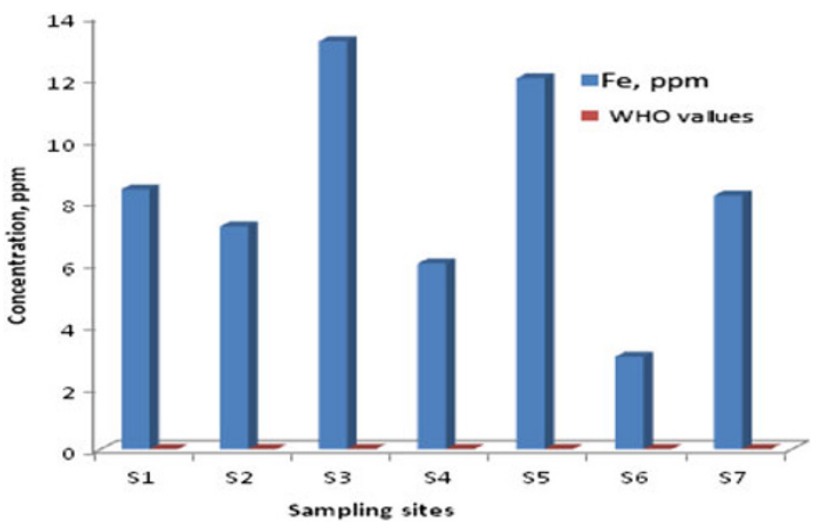

Fig. 1 Mean iron concentration from the Kpeshi lagoon

from industrial facilities or as leachate from landfills and soil (Francis and White 1987). Disposal of mine tailings and liquor in the sea is another source of manganese to the coastal environment, particularly in tropical areas (Florence et al. 1994). The mean manganese concentration in the lagoon water ranged from 0.41 to $1.52 \mathrm{mg} / \mathrm{L}$. The high concentrations of manganese concentration at Site S7 (Fig. 2) could be due to the high exploitation of the cultivable lands at those areas. Measured mean manganese concentration in the fish was $39.28 \pm 4.95 \mathrm{mg} / \mathrm{kg}$. Manganese is difficult to remove from most industrial discharges because the $\mathrm{Ph}$ must be raised to 10 . Aquatic organisms including fishes exhibit toxic responses to manganese in surface waters and hence the need to monitor for levels of manganese in the waters.

Nickel also is a naturally occurring element found in a number of mineral ores including $\mathrm{Ni}$ sulphides, oxides and silicates. The essentiality of $\mathrm{Ni}$ to man has not been demonstrated (Teo and Chen 2001). More attention has been focused on the toxicity of $\mathrm{Ni}$ in low concentrations, such as the fact that $\mathrm{Ni}$ can cause allergic reactions and that certain Ni compounds may be carcinogenic (McKenzie and Smythe 1998). The typical concentrations of $\mathrm{Ni}$ in unpolluted surface water are given as $5.0 \times 10^{-4} \mathrm{mg} / \mathrm{L}$ (DWAF 1996) and $0.015-0.020 \mathrm{mg} / \mathrm{L}$ (Salnikow and Denkhaus 2002).

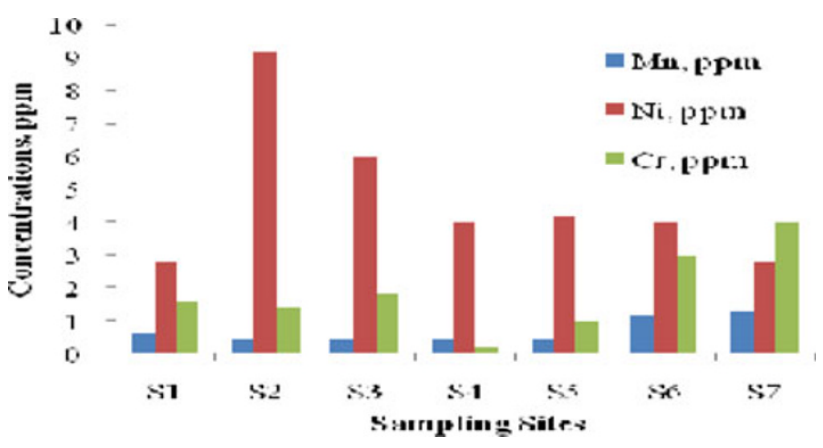

Fig. 2 Mean concentration of $\mathrm{Mn}, \mathrm{Ni}$ and $\mathrm{Cr}$ in the Kpeshi lagoon 


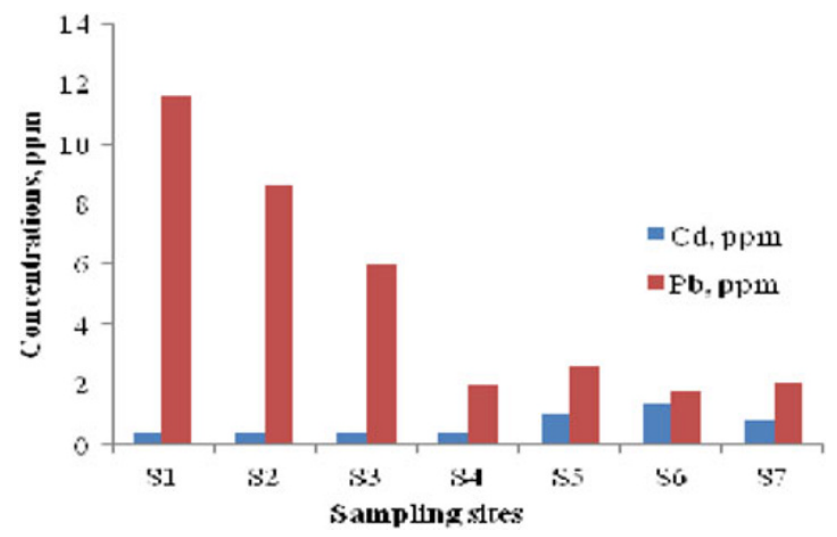

Fig. 3 Mean concentration of $\mathrm{Cd}$ and $\mathrm{Pb}$ from surface water in the Kpeshi lagoon

Table 3 Metals in fish samples

\begin{tabular}{lc}
\hline Elements & Mean concentration $\pm \mathrm{SD}$ \\
\hline $\mathrm{Ca}$ & $15,709.91 \pm 75.35$ \\
$\mathrm{Mg}$ & $5,171 \pm 92.07$ \\
$\mathrm{Na}$ & $3,775.70 \pm 24.80$ \\
$\mathrm{~K}$ & $5,999.94 \pm 87.30$ \\
$\mathrm{Mn}$ & $39.28 \pm 5.43$ \\
$\mathrm{Al}$ & $708.47 \pm 4.95$ \\
\hline
\end{tabular}

The range obtained in this study was much higher (Fig. 2), indicating that the water is contaminated. Possible sources of Ni in surface water include anthropogenic sources, combustion of fossil fuels (Merian 1984), old battery wastes, components of automobiles, old coins, and many other items containing stainless steel and other Ni alloys.

Measured aluminium concentration in the lagoon water ranged from 1.8 to $13.6 \mathrm{mg} / \mathrm{L}$ whilst a mean concentration of $708.47 \mathrm{mg} / \mathrm{kg}$ was measured in the fish samples. The environmental effect of aluminium is that its ions can react with phosphates which cause phosphates to be less available to water organisms. An increased level of aluminium in acidified natural waters is a primary cause of fish death from damage to gill epithelia and loss of osmo-regulatory capacity (Driscoll 1985). Aluminium can also accumulate in plants and cause health problems for animals that consume these plants. In most acidified lakes, the population of fishes and amphibians declines due to reactions of aluminium ions with proteins in the gills of fish and the embryos of frogs. High aluminium concentrations do not only affect fishes, but also harm birds and other animals that consume contaminated fish.

The results of the analyses indicate that concentration of the Cadmium $(\mathrm{Cd})$ varied from 0.4 to $1.4 \mathrm{mg} / \mathrm{L}$; for $\mathrm{Pb}$ it ranged from 1.8 to $11.6 \mathrm{mg} / \mathrm{L}$ and a mean of $4.96 \mathrm{mg} / \mathrm{L}$ (Fig. 3). However, none of these metals were measured in the fish samples from the lagoon. $\mathrm{Cd}$ is one of the most toxic elements with widespread carcinogenic effects in humans and aquatic organisms and is widely distributed in the aquatic environment (Goering et al. 1994). As a consequence of the known toxicity of $\mathrm{Pb}$ and $\mathrm{Cd}$ and of the serious contamination of foods that occur from time to time during commercial handling and processing, most countries monitor the levels of these toxic elements in foods (Table 3).

In order to ascertain sources that affect heavy metals distribution in the wetland, inter-elemental association was evaluated using the Pearson correlation coefficient and the results are presented in Table 4. Elemental association may signify that each paired elements has identical source or common sink in the stream sediments. Strong positive correlation was observed between $\mathrm{Na}$ and $\mathrm{Mg}, \mathrm{K}$ and also between $\mathrm{Mn}$ and $\mathrm{Cr}$. $\mathrm{Ca}$ and $\mathrm{Na}$ also showed strong relations whilst $\mathrm{Mg}$ and $\mathrm{Ca}, \mathrm{Mn}$ and $\mathrm{Cd}, \mathrm{Ni}$ and $\mathrm{Al}, \mathrm{Ca}$ and $\mathrm{Al}$,

Table 4 Pearson correlation analysis of metals in the Kpeshi lagoon

\begin{tabular}{|c|c|c|c|c|c|c|c|c|c|c|c|}
\hline & $\mathrm{Na}, \mathrm{ppm}$ & $\mathrm{K}, \mathrm{ppm}$ & $\mathrm{Ca}, \mathrm{ppm}$ & $\mathrm{Mg}, \mathrm{ppm}$ & $\mathrm{Fe}, \mathrm{ppm}$ & Mn, ppm & $\mathrm{Ni}, \mathrm{ppm}$ & $\mathrm{Cd}, \mathrm{ppm}$ & $\mathrm{Al}, \mathrm{ppm}$ & $\mathrm{Pb}, \mathrm{ppm}$ & $\mathrm{Cr}$, ppm \\
\hline $\mathrm{Na}, \mathrm{ppm}$ & 1.00 & & & & & & & & & & \\
\hline $\mathrm{K}, \mathrm{ppm}$ & 0.96 & 1.00 & & & & & & & & & \\
\hline $\mathrm{Ca}, \mathrm{ppm}$ & 0.64 & 0.73 & 1.00 & & & & & & & & \\
\hline $\mathrm{Mg}, \mathrm{ppm}$ & 1.00 & 0.97 & 0.68 & 1.00 & & & & & & & \\
\hline $\mathrm{Fe}, \mathrm{ppm}$ & -0.51 & -0.56 & -0.60 & -0.48 & 1.00 & & & & & & \\
\hline $\mathrm{Mn}, \mathrm{ppm}$ & -0.20 & -0.10 & -0.13 & -0.22 & -0.48 & 1.00 & & & & & \\
\hline $\mathrm{Ni}, \mathrm{ppm}$ & 0.27 & -0.01 & -0.16 & 0.23 & 0.10 & -0.48 & 1.00 & & & & \\
\hline $\mathrm{Cd}, \mathrm{ppm}$ & 0.18 & 0.27 & -0.24 & 0.13 & -0.39 & 0.65 & -0.33 & 1.00 & & & \\
\hline $\mathrm{Al}, \mathrm{ppm}$ & 0.61 & 0.47 & 0.54 & 0.62 & 0.01 & -0.79 & 0.61 & -0.63 & 1.00 & & \\
\hline $\mathrm{Pb}, \mathrm{ppm}$ & -0.46 & -0.54 & -0.16 & -0.47 & 0.21 & -0.41 & 0.30 & -0.64 & 0.22 & 1.00 & \\
\hline $\mathrm{Cr}, \mathrm{ppm}$ & -0.45 & -0.41 & -0.41 & -0.46 & -0.21 & 0.92 & -0.29 & 0.47 & -0.80 & -0.21 & 1.00 \\
\hline
\end{tabular}

Bold values indicate variables with strong/positive correlation 
$\mathrm{Na}$ and $\mathrm{Al}$ also showed strong correlation. However, Fe and $\mathrm{Na}, \mathrm{K}, \mathrm{Ca}$ showed relatively weak/negative correlation whereas no significant correlation existed between $\mathrm{Mn}$ and $\mathrm{Na}, \mathrm{K}, \mathrm{Ca}, \mathrm{Fe}$; $\mathrm{Ni}$ and $\mathrm{K}, \mathrm{Ca}, \mathrm{Mn} ; \mathrm{Pb}$ and $\mathrm{Ca}, \mathrm{Mg}$; $\mathrm{Cr}$ and $\mathrm{Fe}, \mathrm{Pb}, \mathrm{Ni}$ (Table 4). These weak correlations suggest that the trace elements are not specifically associated with each other and hence are insignificant in the distribution of the elements in the wetland.

\section{Conclusion}

This study was carried out to provide information on heavy metal concentrations in both surface water and the BlackChin tilapia from the Kpeshi lagoon. The concentrations of metals in fish indicate the level of metal pollution of the water from which the fishes were caught. The results of this study supplied valuable information on the metal levels in black-chin tilapia from the Kpeshi lagoon. This could be considered a bio-indicator of environmental contamination within this zone by estimating the bioavailability of metal to the freshwater biota. In this regard, the low metal concentrations found in studied fish samples are insufficient to have any toxicological effects on human health when these fish are included in the diet. It is however suggested that heavy metal pollution of the lagoon should be checked and monitored regularly for environmental pollutions. Due emphasis need to be given to the study of metal distribution on a temporal basis, so that contributions of manmade and natural effects may be assessed

Open Access This article is distributed under the terms of the Creative Commons Attribution License which permits any use, distribution, and reproduction in any medium, provided the original author(s) and the source are credited.

\section{References}

Addo MA, Okley GM, Affum HA, Acquah S, Gbadago JK, Senu JK, Botwe BO (2011) Water quality and level of some heavy metals in water and sediments of Kpeshie lagoon, La-Accra, Ghana. Res J Environ Earth Sci 3(5):487-497

AOAC (1995) Official methods of analysis, 16th edn. Arlington, AOAC

APHA (1992) Standard methods for the examination of water and waste water, 18th edn. American Public Health Association Washington, DC, APHA-AWWWA-WEF

Biney CA (1982) Preliminary survey of the state of pollution of the coastal environment of Ghana. Oceanol Acta SP 4(Suppl):39-43

Biney CA (1984) Preliminary studies on coastal pollution in Ghana: oxygen, nutrients and some physical properties. Oceanol Acta pp 43

Biney CA (1986) Preliminary physico-chemical studies of estuaries along the Gulf of Guinea in Ghana. Trop Ecol 27:147-156

Biney CA (1990) A review of some characteristics of freshwater and coastal ecosystems in Ghana. Hydrobiologia 208:45-53
Biney CA, de Graft-Johnson KAA, Opoku AA (1995) The state of wetlands in Ghana. Technical Report Number 144. Institute of Aquatic Biology, Achimota, Ghana

Chapman D (1992) Water quality assessment: a guide to the use of biota, sediments and water in environmental monitoring. University Press, Cambridge

Cloern JE (1996) Phytoplankton bloom dynamics in coastal ecosystems: a review with some general lessons from sustained investigation of San Francisco Bay, California. Rev Geophys 34:127-168

Cunningham WP, Saigo BW (1997) Environmental science: a global concern, 4th edn. Wm. C. Brown Publishers, Dubuque, $634 \mathrm{p}$

Davies B, Day J (1998) Vanishing waters. University of Cape Town Press, Cape Town

Department of Water Affairs \& Forestry, DWAF (1996) South African Water Quality Guidelines, Field Guide, vol. 8, 1st edn. DWAF, Pretoria

Driscoll CT (1985) Aluminum in acidic surface waters: chemistry, transport and effects. Environ Health Perspect 66:93-104

Fianko JR, Osae S, Achel D (2008) Impact of anthropogenic activities on the Densu River in Ghana. Water Environ J 23(3):229-234

Florence TM, Stauber JL, Ahsanullah M (1994) Toxicity of nickel ores to marine organisms. Sci Total Environ 148:139-155

Francis CW, White GH (1987) Leaching of toxic metals from incinerator ashes. J Water Pollut Control Fed 59:979-986

Goering PL, Waalkes MP, Klaassen CD (1994) Toxicology of metals. In: Goyer RA, Cherian MG (eds) Handbook of experimental pharmacology, vol 115. Springer, New York, p 189

Gordon C (1995) Muni-Pomadze Ramsar site: aquatic ecology. Ghana Coastal Wetland Management Project. Department of Game and Wildlife, Government of Ghana, pp 45

Hesse PR (ed) (1971) A textbook of soil chemical analysis. Murray, London, pp 513

Kandemir S, Ilker Dogru M, Orun I, Dogru A, Altas L, Erdogan K, Orun G, Polat N (2010). Determination of heavy metal levels, oxidative status, biochemical and hematological parameters in Cyprinus carpio L., 1758 from Bafra (Samsun) Fish Lakes. J Animal Vet Adv 9(3):617-622

Koukal B, Dominik J, Vignati D, Arpagaus P, Santiago S, Benaabidate L (2004) Assessment of water quality and toxicity of polluted rivers $\mathrm{Fez}$ and Sebou in region of Fez (Morocco). Environ Pollut 131:163-170

Kwei EA (1977) Biological, chemical and hydrological characters of coastal lagoons of Ghana, West Africa. Hydrobiologia 56:157174

Laar C, Fianko JR, Akiti TT, Osae S, Brimah AK (2010) Determination of heavy metals in the Black-chin Tilapia from the Sakumo lagoon, Ghana. Res J Environ Earth Sci 3(1):8-13

McKenzie HA, Smythe LE (eds) (1998) Quantitative trace analysis of biological materials. Elsevier, Amsterdam, pp 487

Merian E (1984) Introduction on environmental chemistry and global cycles of chromium, nickel, cobalt, beryllium, arsenic, cadmium, and selenium, and their derivatives. Toxicol Environ Chem 8:9-38

Palmateer GA (1992) Transport of biological pollutants from agricultural sources through aquatic sediments systems in Ontario. In: Miller MH, Fitzgibbon JE, Fox GC, Gilham RW, Whiteley HR (eds) Agriculture and water quality: proceedings of an interdisciplinary symposium, April 23-24, 1991. Centre for Soil and Water Conservation, Guelph, Ontario, Canada, pp 59-77

Peirce JJ, Weiner RF, Vesilind PA (1997) Environmental pollution and control, 4th edn. Butterworth-Heinemann, Woburn, pp 57-74

Salnikow K, Denkhaus E (2002) Nickel essentiality, toxicity, and carcinogenicity. Crit Rev Oncol/Haematol 42(1):35-56 
Sherman A, Sherman SJ (1989) Chemistry and our changing world, 2nd edn. Prentice Hall Englewood Cliffs, New Jersey

Smith VH, Tilman GD, Nekola JC (1999) Eutrophication: impacts of excess nutrient inputs on freshwater, marine, and terrestrial ecosystems. Environ Pollut 100:179-196

Swift DR (1993) Aquaculture training manual, 2nd edn. Fishing News Books, London, UK, pp 158

Teo KC, Chen J (2001) Determination of cobalt and nickel in water samples by flame atomic absorption spectrometry after cloud point extraction. Anal Chim Acta 434(2):325-330
Wild A (1995) Soils and the environment: an introduction. University Press, Cambridge, UK, pp 287

WRC (2003) Groundwater assessment: an element of integrated water resources management-the case of Densu River basin. Technical report, Water Resources Commission, Accra

Yilmaz S, Toy S, Irmak MA, Yilmaz H (2007) Determination of climatic differences in three different land uses of the city Erzurum, Turkey. Build Environ 42:1604-1612 